\begin{tabular}{|l|l|l||}
\hline \multicolumn{2}{|c|}{ PublisherInfo } \\
\hline \hline PublisherName & $:$ & BioMed Central \\
\hline \hline PublisherLocation & $:$ & London \\
\hline \hline PublisherImprintName & $:$ & BioMed Central \\
\hline \hline
\end{tabular}

\title{
New model of leukocyte arrest
}

\begin{tabular}{|l|l|l||}
\hline \multicolumn{2}{|c|}{ ArticleInfo } \\
\hline \hline ArticleID & $:$ & 5078 \\
\hline \hline ArticleDOI & $:$ & $10.1186 /$ gb-spotlight-20050418-01 \\
\hline \hline ArticleCitationID & $:$ & spotlight-20050418-01 \\
\hline \hline ArticleSequenceNumber & $:$ & 54 \\
\hline \hline ArticleCategory & $:$ & Research news \\
\hline ArticleFirstPage & $:$ & 1 \\
\hline \hline ArticleLastPage & $:$ & 3 \\
\hline \hline & & RegistrationDate : 2005-4-18 \\
\hline ArticleHistory & $:$ & OnlineDate \\
\hline \hline ArticleCopyright & $:$ & BioMed Central Ltd2005-4-18 \\
\hline \hline ArticleGrants & $:$ & \\
\hline \hline ArticleContext & $:$ & 130596611 \\
\hline \hline
\end{tabular}


Lymphocytes rolling on high endothelial venules stop abruptly in response to chemokines presented by endothelial cells, according to a report published online in Nature Immunology today (April 18). The finding challenges previous notions of the mechanism of leukocyte arrest.

Ronen Alon, of the Weizmann Institute of Science, Rehovot, Israel, and colleagues found that chemokines trigger instantaneous extension of the LFA-1 integrin - an adhesion molecule that can change between an inactive, bent conformation and an active, extended conformation. "The chemokinemediated extension generates an intermediate affinity form of LFA-1, which brings the integrin head piece into close proximity with the adhesion molecule ICAM-1," Alon told The Scientist. "Then, ICAM-1 triggers the conversion to high affinity."

The physiological and biochemical data that the authors present argues for an integrin activation that happens in 0.1 to 0.5 seconds, resulting in a sudden arrest. "For a long time, it was believed that cells are rolling and integrating chemoattractant signals over periods of a few seconds," said Alon. "We argued against this idea because if a cell starts to roll, it should get slower, but we found no evidence of deceleration. In immunological synapses, for example, integrins have to go through some kind of activation, but that activation is not that fast."

Theoretically, there are four levels of integrin signalling: "inside-out," or intracellular to extracellular signaling; "outside-in," or extracellular to intracellular signaling; "anchorage," in which integrins anchor to the cytoskeleton; and "clustering," in which integrins flow and get recruited, stabilizing adhesion.

"Many labs supported the idea that integrins regulate adhesion merely by clustering," explained Alon. "It was very hard to prove mechanistically that the three other levels can happen within a fraction of a second."

In their latest paper, Alon and colleagues propose that the chemokine activation process of the LFA-1 integrin is "biconditional," involving inside-out as well as outside-in conformational arrangements of individual integrin molecules.

M. Amin Arnaout of Harvard Medical School, Boston, Mass., who did not participate in the research, said he found the functional data "pretty good," but called for caution with the structural underpinning of those data. "The reporter mAb 24 that [the authors] used is a known activation reporter, but it's not believed to reflect the extended state of an integrin," said Arnaout. He also mentioned two recent papers, which found that, contrary to what was previously believed, the bent integrin conformation is able to stably bind physiologic ligands.

On the other hand, Michael L. Dustin of New York University Medical Center, who was not involved in the research, was not concerned about the use of the mAb 24 reporter. "I wouldn't complain about the interpretation of the $\mathrm{mAb} 24$ data since [the authors] looked at three other antibodies, one of which is structurally a very good extension reporter," Dustin said in an E-mail.

According to Arnaout, this paper also opens another controversy regarding the relative importance of integrin avidity (receptor clustering) versus affinity switching (conformational change) in adhesion. 
"Previous work by the authors showed that immobilized chemokines rapidly augment reversible subsecond lymphocyte adhesion through a change in integrin avidity, not affinity. It may be that the relative importance of avidity versus affinity varies with the integrin and the particular system used for evaluation," said Arnaout.

Alon said that is indeed the case: "I'm not working on the same integrin that I worked on before. The avidity [argument] was for VLA-4, and this paper is on LSA-1, a completely new integrin." Alon remarked that although in this paper they favor the affinity mechanism, they are not excluding others. "We propose that microclustering is also involved, and microclustering takes you back to avidity."

"I think they simply have new data that forces them to reject the earlier ideas and embrace a new model, which is closer to reality. This is the way science moves forward," said Dustin.

\section{References}

1. R. Shamri et al., "Lymphocyte arrest requires instantaneous induction of an extended LFA-1 conformation mediated by endothelium-bound chemokines," Nat Immunol, DOI:10.1038/ni1194, April 17, 2005., [http://www.nature.com/natureimmunology/]

2. Ronen Alon, [http://www.weizmann.ac.il/immunology/AlonPage.html]

3. M.M. Davis, "Vision: Panning for T-cell gold," The Scientist, July 19, 2004., [http://www.thescientist.com/2004/7/19/28/1]

4. J.P. Roberts, "Dissecting the immunological synapse," The Scientist, May 5, 2003., [http://www.thescientist.com/2003/5/5/28/1]

5. M. Amin Arnaout, [http://receptor.mgh.harvard.edu/Investigators/Arnaout/MAA.html]

6. Michael L. Dustin, [http://www.med.nyu.edu/people/dustim01.html] 